\title{
Articulo Original / Original Article \\ In vitro and in vivo antioxidant potentials of the methanolic crude extract from Inula glomerata Oliv. \& Hiern (Asteraceae) and Salacia kraussii (Harv.) Harv (Celastraceae)
}

[Potenciales antioxidantes in vitro e in vivo del extracto crudo metanólico de Inula glomerata Oliv. \& Hiern. (Asteraceae) y Salacia kraussii (Harv.) Harv (Celastraceae)]

\author{
Michael C Ojo ${ }^{1}$, Foluso O Osunsanmi ${ }^{2}$, Nkosinathi D Cele ${ }^{1}$, Godfrey E Zharare ${ }^{2}$, \\ Rebamang A Mosa ${ }^{3} \&$ Andy R Opoku ${ }^{1}$
}

\footnotetext{
${ }^{1}$ Department of Biochemistry and Microbiology, University of Zululand, KwaDlangezwa 3886, Republic of South Africa

${ }^{2}$ Department of Agricultural Science, University of Zululand, KwaDlangezwa 3886, Republic of South Africa

${ }^{3}$ Biochemistry, Genetics \& Microbiology Department; Biochemistry Division, Faculty of Natural \& Agricultural Science. University of Pretoria, Hatfield, Republic of South Africa
}

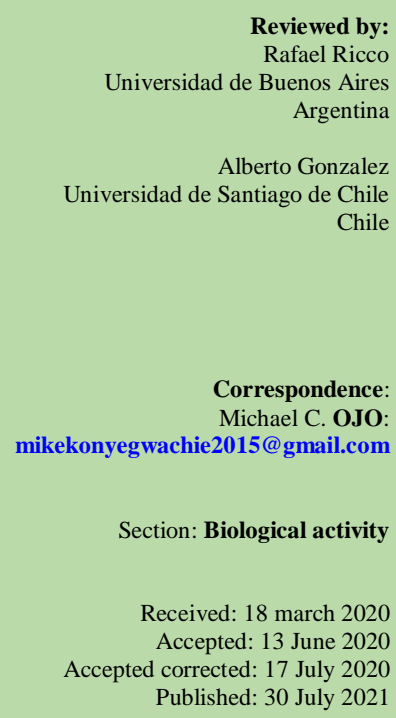

Citation:

Ojo MC, Osunsanmi FO, Cele ND, Zharare GE, Mosa RA, Opoku AR. In vitro and in vivo antioxidant potentials of the methanolic crude extract from Inula glomerata Oliv. \& Hiern (Asteraceae) and Salacia kraussii (Harv.) Harv (Celastraceae)

Bol Latinoam Caribe Plant Med Aromat 20 (4): 416 - 426 (2021). https://doi.org/10.37360/blacpma.21.20.4.31
Abstract: Reactive oxygen species are implicated in multiple pathological conditions including erectile dysfunction. This study evaluated the in vitro and in vivo antioxidant potential of the methanolic extracts of Inula glomerata and Salacia kraussii. The plant materials were pulverized and extracted with methanol. The phytochemical analysis, ability of the crude extracts to scavenge free radicals (ABTS, $\mathrm{DPPH}, \mathrm{NO}$.) in vitro as well as the total phenolic and flavonoid contents was investigated. In vivo, antioxidant potentials of the crude extracts $(50 / 250 \mathrm{mg} / \mathrm{kg}$ body weight) were determined in an erectile dysfunction rat model. The phytochemical analysis revealed that both plants contain flavonoids, tannins, terpenoids, and alkaloids. The crude extracts at varying degree of efficiency, scavenged ABTS and DPPH radicals. The crude extracts at low concentrations $(50 \mathrm{mg} / \mathrm{kg} \mathrm{b} . \mathrm{w})$ significantly $(p<0.05)$ diminished the level of malondialdehyde, augmented catalase activities and elevated glutathione levels. However, SOD activities were significantly boosted in a dose-dependent manner by the crude extracts. Therefore, $I$. glomerata and S. kraussii possess antioxidant properties, hence, can serve as a therapeutic modality in the treatment of oxidative stress-induced erectile dysfunction.

Keywords: Antioxidants; Free radicals; Reactive oxygen species; Oxidative stress; Inula glomerata; Salacia krausii.

Resumen: Las especies reactivas de oxígeno están implicadas en múltiples condiciones patológicas, incluyendo la disfunción eréctil. Este estudio evaluó el potencial antioxidante in vitro e in vivo de extractos metanólicos de Inula glomerata y Salacia kraussii. Los materiales vegetales fueron pulverizados y extraídos con metanol. A estos extractos crudos se les llevó a cabo el análisis fitoquímico junto con el contenido total de fenólicos y flavonoides, así como se les investigó la capacidad in vitro para atrapar radicales (ABTS, DPPH, NO.). Los potenciales antioxidantes in vivo de los extractos crudos $(50 / 250 \mathrm{mg} / \mathrm{kg}$ de peso corporal) se determinaron en un modelo en ratas con disfunción eréctil. El análisis fitoquímico reveló que ambas plantas contuvieron flavonoides, taninos, terpenoides y alcaloides. Los extractos crudos con un grado variable de eficiencia, atraparon a los radicales ABTS y DPPH. Los extractos crudos a bajas concentraciones $(50 \mathrm{mg} / \mathrm{kg}$ p.c) significativamente $(p<0.05)$ disminuyeron el nivel de malondialdehído, aumentaron las actividades de catalasa y elevaron los niveles de glutatión. Sin embargo, las actividades de SOD por los extractos crudos fueron significativamente dosis-dependientes. Así, los extractos de I. glomerata y $S$. kraussii mostraron propiedades antioxidantes, y por lo tanto, podrían servir como una alternativa terapéutica en el tratamiento de disfunción eréctil inducida por estrés oxidativo.

Palabras clave: Antioxidantes; Radicales libres; Especies reactivas de oxígeno; Estrés oxidativo; Inula glomerata; Salacia krausii. 


\section{INTRODUCTION}

Free radicals also known as reactive species (reactive oxygen species and nitric oxide), are chemically reactive molecules that can be by-products of biological reactions such as activation of neutrophils, mitochondria oxidative phosphorylation and autoxidation of dopamine (Pendyala et al., 2008; Halliwell, 2011; Lawal et al., 2015; Reena et al., 2018). Under physiological conditions, free radicals enhance signaling molecules and destruction of antigens or foreign invaders consequently, boosting immunity and promoting good health (Bhakuni et al., 2005; Halliwell, 2011). Nevertheless, when reactive oxygen species are overproduced or the antioxidant system has been compromised, oxidative stress occurs. Oxidative stress causes protein and DNA damage, abortive apoptosis, lipid peroxidation, and oligoasthenoteratozoospermia. These products of oxidative stress have been implicated in most pathological abnormalities such as erectile dysfunction, cancer, hyperplastic diseases, diabetes, male infertility, hypertension, immune system retrogression, myocardial ischemia-reperfusion injury, build-up of cataract, as well as aging process (Tsao \& Deng, 2004; Buford, 2016; Majzoub \& Agarwal, 2017; Ojo et al., 2019). Endogenous antioxidants' enzymes such as superoxide dismutase and catalase as well as other compounds like reduced glutathione, peroxiredoxins, vitamin $\mathrm{C}$ (Ascorbic acid), D (Cholecalciferol), E (tocopherol), and betacarotene help to cushion the deleterious effects of free radicals in cells and tissues (Halliwell, 2011; Ojo et al., 2019). In addition, fruits, herbs, spices, and vegetables contain naturally occurring compounds that mitigate free radicals- induced diseases, thus, further boosting the total antioxidant capacity of the body (Halliwell, 2011; Lavanya et al., 2019). Naturally occurring antioxidant compounds have gained much interest lately because of their affordability, accessibility and most importantly are devoid of adverse effects (Lavanya et al., 2019).

Inula glomerata Oliv. \& Hiern indigenous to Northern South Africa, Zimbabwe, Angola, and Tanzania belongs to the Asteraceae family (Burrows \& Willis, 2005). It is about $2 \mathrm{~m}$ tall with a basal rosette leaves with an irregularly toothed margin. Although there is a dearth of information on the bioactivities of $I$. glomerata, the roots are said to be used for treating hypertension (oral communication yet to be validated scientifically). Furthermore, the roots of its closely related species, I. racemosa
Hook.f. is used in the treatment and management of tuberculosis, dyspnoea and angina as well as to enhance insulin sensitivity. The pharmacological effects exerted by $I$. racemosa is attributed to the presence of bioactive compounds such as alantolactone, dihydroalantolactone, isonunal, inunolide, aplotaxene etc. The aqueous extracts of $I$. racemosa also contains phytochemicals including saponins, phenols, flavonoids, terpenoids and glycosides (Tan et al., 1998; Arumugam et al., 2012). Salacia kraussii (Harv.) Harv commonly called Ibhonsi is an annual suffrutex with shoots from rhizome or shrubs that is up to 1-3 m tall belonging to the Celastraceae family. $S$. kraussii is endemic to Southern Africa including South Africa (Kwazulu Natal) and possesses anti-diarrhoea and anti-malaria efficacy (Bandeira et al., 2001; Raimondo et al., 2009). In addition, the roots and stems of several Salacia species including Salacia oblonga (S. oblonga), Salacia chinensis (S. chinensis) and Salacia reticulata (S. reticulata) possess medicinal properties against rheumatism, gonorrhea, skin diseases and diabetes. Specifically, two bioactive compounds namely salacinol and kotalanol isolated from Salacia plants have been scientifically validated to exhibit anti-hyperglycaemic effect via $\alpha$ glucosidase inhibition (Muraoka et al., 2010).

The leaves of Inula glomerata Olive \& Hiern and roots of Salacia kraussii (Harv.) Harv are used by traditional healers for managing erectile dysfunction, one of several free radicals mediated disorders but has not been scientifically validated. So, this study aimed at evaluating the in vitro and in vivo antioxidant capacity of the methanolic extracts of these plants.

\section{MATERIALS AND METHODS Chemicals}

All the chemicals and kits used in this study were purchased from Sigma Aldrich Co.Ltd (Steinheim, Germany) and are of analytical grades.

\section{Plant Identification}

The roots of Salacia kraussii (Harv.) Harv and leaves of Inula glomerata Oliv. \& Hiern were collected from Mbazwana (27 $15^{\prime} 11.3$ " S 32²8'14.3" E) KwaZulu Natal, South Africa. The plants were authenticated at the Department of Botany, the University of Zululand by Dr. Ntuli. The plants with specimen number V04 and V06 were deposited at the university's herbarium. 


\section{Plant Extraction}

The roots of Salacia kraussii (Harv.) Harv and leaves of Inula glomerata Olive. \& Hern respectively were cleaned, washed, air-dried at room temperature, and pulverized into fine powder. Pulverized samples (200 $\mathrm{mg})$ were extracted with methanol $(1: 5 \mathrm{w} / \mathrm{v})$ and incubated on a mechanical shaker $\left(150 \mathrm{rpm} ; 25^{\circ} \mathrm{C}\right)$ for $72 \mathrm{~h}$. The extract was filtered using Whatman filter paper (No. 1) and concentrated using Heidolph rotary evaporator $\left(40^{\circ} \mathrm{C}\right)$.

\section{Phytochemical screening}

The pulverized samples were screened for the presence of phytochemicals using the method of Odebiyi \& Sofowora, (1978), and Harbone, (1973). Tannins, saponins, flavonoids, alkaloids, terpenoids, and steroids were the phytochemicals screened for.

\section{Test for Saponin}

The plant materials $(2.5 \mathrm{~g})$ were extracted with boiling water $(5 \mathrm{~mL})$ and allowed to cool. The froth that appeared after the extract was shaken and allowed to stand for 15-20 mins determines the presence of saponin. In addition, depending on the size $(1-2 \mathrm{~cm})$ of the froth, saponin was classified as weakly, high, and strongly positive.

\section{Test for Tannins}

Boiling water $(10 \mathrm{~mL})$ was added to $0.5 \mathrm{~g}$ plant material for 15 mins and filtered. The filtrate was made up to $10 \mathrm{~mL}$ with distilled water thereafter, 2 $\mathrm{ml}$ of the filtrate was transferred into another test tube and $0.1 \%$ of $\mathrm{FeCl}_{3}$ was added. A blue-black, green, or blue green confirmed the presence of tannins.

\section{Test for Steroids}

To $2 \mathrm{~mL}$ each of acetic anhydride and concentrated sulphuric acid, $0.5 \mathrm{~g}$ of the plant was added and mixed. A colour change from violet to blue or green indicated the presence of steroids.

\section{Test for Alkaloids}

The plant material $(0.5 \mathrm{~g})$ was dissolved in $5 \mathrm{~mL} 1 \%$ $\mathrm{HCl}$ (aq) on a steam bath, stirred and filtered. The filtrate $(1 \mathrm{~mL}$ each) was then put into two different test tubes. The first portion was treated with Mayer's reagent and a precipitate formation confirms the presence of alkaloids. Treatment with Dragendorff's reagent and the subsequent presence of turbidity or a precipitate indicates the presence of alkaloids.

\section{Test for Flavonoids}

The lead acetate, sodium hydroxide or ferric chloride test can be used to confirm the presence of flavonoids.

\section{Lead acetate test for flavonoids}

The presence of a reddish-brown colouration or precipitate after $1 \mathrm{~g}$ of the plant material was mixed with $1 \mathrm{~mL}$ of $10 \%$ lead acetate was taken as an evidence that flavonoid is present.

\section{Sodium hydroxide test for flavonoids}

Dilute sodium hydroxide $(1 \mathrm{~mL})$ was added to the plant material $(1 \mathrm{~g})$ in a test tube. A golden yellow precipitate indicates flavonoid presence.

\section{Ferric chloride test for flavonoids}

The plant material $(1 \mathrm{~g})$ was mixed with $1 \mathrm{~mL} \mathrm{Fecl}_{3}$. A dark brown or dirty brown colouration or precipitate is an evidence that flavonoid is present.

\section{Test for Terpenoids}

Chloroform $(2 \mathrm{~mL})$ was mixed with the plant material $(0.5 \mathrm{~g})$ thereafter, $3 \mathrm{~mL}$ of concentrated sulphuric acid was carefully added to form a layer. The presence of reddish-brown colouration at the interface, was taken as evidence that terpenoid is present.

\section{Total Phenolic Content (TPC)}

The phenolic content of the crude extracts was measured using the Folin-Ciocalteu reagent as described by Kujala et al. (2000) method. The crude extracts $(0.2 \mathrm{mg} / \mathrm{mL})$ was added to $1.5 \mathrm{~mL}$ diluted Folin-Ciocalteu reagent $(1: 10 \mathrm{v} / \mathrm{v})$ and $1.2 \mathrm{~mL}$ of sodium carbonate solution $(7.5 \%)$. The reaction mixture was incubated in the dark at room temperature for $30 \mathrm{~min}$. Absorbance was then read at $765 \mathrm{~nm}$ and the total phenolic content of the crude extracts was determined as gallic acid equivalent in $\mathrm{mg} / \mathrm{g}$ dry plant material.

\section{Total Flavonoid Content (TFC)}

The total flavonoid content of the crude extracts was estimated using the method of Ordonez et al. (2006). The crude extracts $(0.2 \mathrm{mg} / \mathrm{mL})$ was well mixed together with aluminium chloride $(0.5 \mathrm{~mL} ; 2 \%)$. The reaction mixture was then incubated for $1 \mathrm{hr}$ at $25^{\circ} \mathrm{C}$. Thereafter, absorbance was read at $420 \mathrm{~nm}$. The total flavonoid content of the crude extracts was calculated from the quercetin calibration curve and expressed as quercetin equivalent in $\mathrm{mg} / \mathrm{g}$ dry plant material.

\section{Boletín Latinoamericano y del Caribe de Plantas Medicinales y Aromáticas/418}




\section{1,1-Diphenyl-2-Picryl Hydrazyl (DPPH) Scavenging activity}

The method of Brand-Williams et al. (1995) was used for evaluating the scavenging activity of the crude extracts on DPPH. The total reaction mixture volume contains $(1: 1 \mathrm{v} / \mathrm{v})$ different concentrations of the crude extracts $(0-4 \mathrm{mg} / \mathrm{mL})$ and DPPH $(0.02$ $\mathrm{mg} / \mathrm{mL}$ ). The mixture was made to stand for $30 \mathrm{~min}$ under diffused light at $25^{\circ} \mathrm{C}$ and the absorbance was read at $517 \mathrm{~nm}$ with the aid of a Biotek plate reader. Butylated Hydroxyl Anisole (BHA) and Ascorbic acid (AA) served as positive controls.

\section{2,2 ${ }^{1}$-Azino-bis (3-ethylbenzothiazoline-6-sulfonic acid) diammonium salt (ABTS) Scavenging activity}

The scavenging activity of the crude extracts on ABTS was determined by the method of Re et al. (1999). The ABTS radical was generated overnight (16 h) by mixing $2.5 \mathrm{mM}$ potassium persulfate with 7 $\mathrm{mM}$ of ABTS. Thereafter, the ABTS solution was diluted with methanol (1:60). ABTS solution was then added to different concentrations of the crude extracts at a ratio of $1: 1(\mathrm{v} / \mathrm{v})$. The reaction mixture was incubated for $10 \mathrm{~min}$ in the dark at $25^{\circ} \mathrm{C}$ and absorbance was taken at $734 \mathrm{~nm}$ using a Biotek plate reader. The positive controls were AA and BHA.

\section{Nitric oxide (NO') scavenging activity}

The scavenging activity of the crude extracts on nitric oxide radical was investigated using the method of Badami et al. (2005). The reaction mixture consists

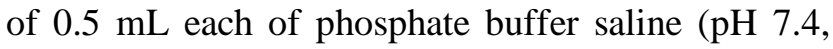
$0.1 \mathrm{M})$ and different concentrations of crude extracts $(0-5 \mathrm{mg} / \mathrm{mL})$ with $2 \mathrm{ml}$ of sodium nitroprusside (10 $\mathrm{mM})$. The mixture was well mixed and incubated at $25^{\circ} \mathrm{C}$ for $150 \mathrm{~min} .1 \mathrm{~mL}$ of sulphanilic acid reagent (0.33\% sulphanilic acid in $20 \%$ glacial acetic acid) was added to $0.5 \mathrm{~mL}$ aliquot from the reaction mixture. The resultant mixture was allowed to stand for $5 \mathrm{~min} 0.1 \mathrm{~mL}$ Naphthylethylenediamine dihydrochloride (1\%) was added and mixed together, thereafter incubated under diffused light for $30 \mathrm{~min}$. Absorbance was read at $540 \mathrm{~nm}$ and AA with BHA served as a positive control.

\section{Animal experiment}

Ethical clearance certificate (UZREC 171110-030 PGM 2018/576) was obtained from the University of Zululand Ethics committee for the use of animal experiments. The standard operating procedures for experimental animals were adhered according to Public Health Service policy (2002). Male Sprague-
Dawley rats $(250 \mathrm{~g})$ were collected from the animal house of the Department of Biochemistry and Microbiology, University of Zululand. The animals were kept under conducive environmental conditions $\left(25^{\circ} \mathrm{C} ; 12: 12\right.$ light: dark cycle) with free access to safe drinking water and pellet feeds. The animals were acclimatized for 5 days before the experiment commenced.

\section{Animal model}

The method of Garza et al. (2015). with slight modification was followed to perform the animal experiment. Thirty-five male Sprague-Dawley rats were collected and asymmetrically divided randomly into two groups (normal control and n-butanol group). The n-butanol group (30) were injected interperitoneally with n-butanol $(5 \mathrm{mg} / \mathrm{kg} \mathrm{b.w})$ for four days at two days interval to induce erectile dysfunction. Afterward, each animal was allowed to mate with two estrous female rats (injected with estradiol $7.5 \mathrm{mg} / \mathrm{kg}$ b.w for 2 days at $24 \mathrm{~h}$ interval) to establish the baseline of their sexual prowess. After establishing that erectile dysfunction has been induced (Reduced mounting frequency in the male rats belonging to the n-butanol group as compared to the normal group was used as a confirmation that erectile dysfunction has been induced), they were further divided into 6 groups (5 rats/group) and given daily oral medications for 28 days. The treatment regime for 28 days was as follows:

Group 1 (normal control): received only water and pellet feeds

Group 2 treated with Salacia kraussii at $50 \mathrm{mg} / \mathrm{kg}$ b.w

Group 3 treated with Inula glomerata at $50 \mathrm{mg} / \mathrm{kg}$ b.w

Group 4 (untreated): received only water and pellet feeds (negative control)

Group 5 treated with $250 \mathrm{mg} / \mathrm{kg}$ b.w

Group 6 treated with $250 \mathrm{mg} / \mathrm{kg}$ b.w

Group 7 treated with Cialis at $5 \mathrm{mg} / \mathrm{b} . \mathrm{w}$ (positive control).

After the experiment has elapsed, the rats were euthanized under anesthesia, blood was immediately collected by cardiac puncture for biochemical analysis of the antioxidant status of the serum.

\section{In-vivo Antioxidant Studies}

The activities of Superoxide dismutase (SOD), Catalase (CAT) as well as the level of glutathione and malondialdehyde in the sera were determined

\section{Boletín Latinoamericano y del Caribe de Plantas Medicinales y Aromáticas/419}


using standard analytical grade kits from Sigma Aldrich and following manufacturer's instructions.

\section{Data analysis}

All experiments were carried out in triplicates and data was expressed as mean \pm standard deviation. Analysis of the data was done with one-way analysis of variance (ANOVA) and $\mathrm{IC}_{50}$ values were determined using the graph pad prism. The percentage (\%) scavenging activities of the crude extracts were estimated using the formula;

$\%$ scavenging activity $\left.=\left(\mathrm{A}_{0}-\mathrm{A}_{1}\right) / \mathrm{A}_{0}\right) \times 100$. Molar extinction co-efficient (£) $\mathrm{AA}=4.14 \times 10^{4} \mathrm{~L} / \mathrm{mol} \mathrm{cm}$ ) where $\mathrm{A}_{0}$ is the absorbance value of the control and A1 is the absorbance of the crude extracts.

\section{RESULTS}

Percentage Yield

The crude extracts' yield of Inula glomerata was $8.5 \%$ while that of Salacia krausii was $5.97 \%$.

\section{Phytochemical analysis}

The phytochemical screening of the plants revealed that both plants contained tannins, flavonoids, terpenoids and alkaloids as depicted in Table No. 1. However, steroids were only present in S. kraussii.

Table No. 1

Phytochemicals of I. glomerata and S. kraussii

\begin{tabular}{lll}
\hline Phytochemicals & Inula glomerata & Salacia kraussii \\
\hline Alkaloids & + & + \\
Flavonoids & + & + \\
Saponins & - & - \\
Steroids & - & + \\
Tannins & + & + \\
Terpenoids & + & + \\
\hline
\end{tabular}

Sign notations: + present, - Absent

\section{Total Phenolic and Flavonoid Content}

The phenolic and flavonoid contents of I. glomerata and $S$. kraussii are depicted in Figure No. 1a and Figure No. 1b respectively. I. glomerata contained significantly $(p<0.05)$ higher phenolic than S.kraussii. In addition, the flavonoid content was higher in I. glomerata than S. krausii however, nonsignificantly. 


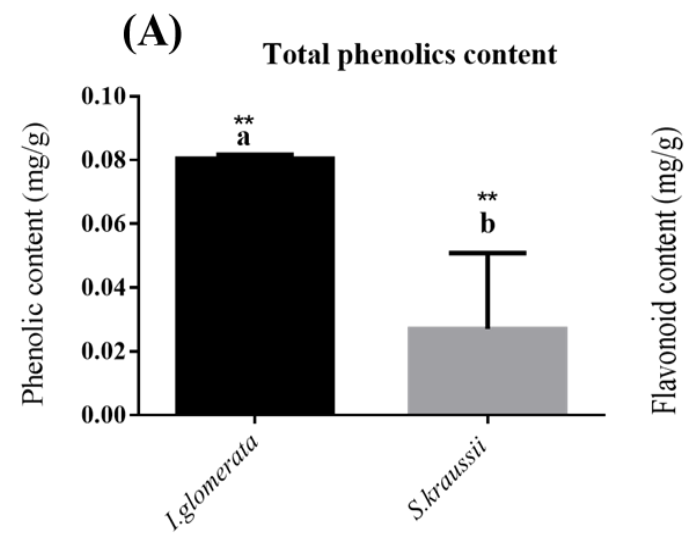

Figure No. 1

(a) Phenolic content of Inula glomerata and Salacia krausii (b) Flavonoid content of Inula glomerata and Salacia krausii. Key words ** very significant.DPPH scavenging activity

extracts displayed concentration-dependent scavenging activities on DPPH that was in overall poor as shown in Figure No. 2a.

\section{ABTS Scavenging activity}

The scavenging activity of both plants 'crude extracts on ABTS is depicted in Figure No. 2b. The result showed that both crude plants' extracts scavenged ABTS at varying degrees of efficiency that was concentration-dependent but Salacia kraussii exhibited better scavenging activity $\left(\mathrm{IC}_{50} 0.00658\right.$ $\mathrm{mg} / \mathrm{mL}$ ) than ascorbic acid ( $\left.\mathrm{IC}_{50} 0.0127 \mathrm{mg} / \mathrm{mL}\right)$.
(A)

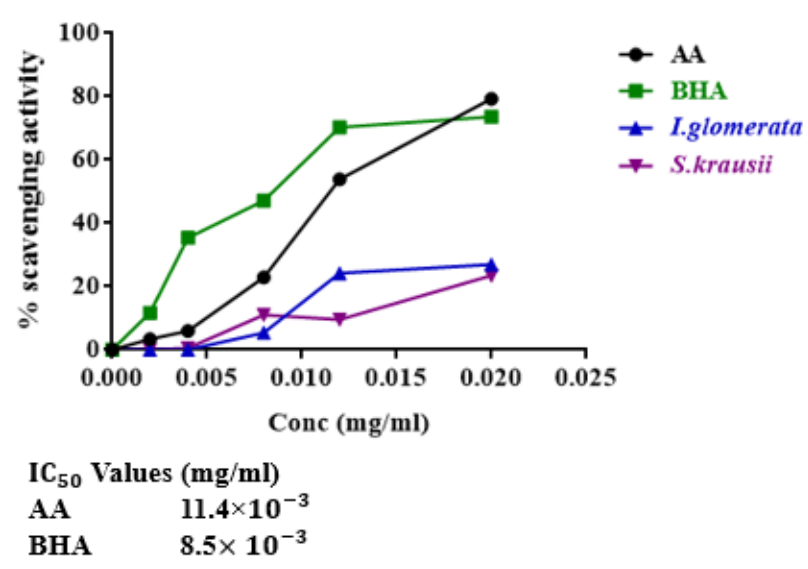

(B)

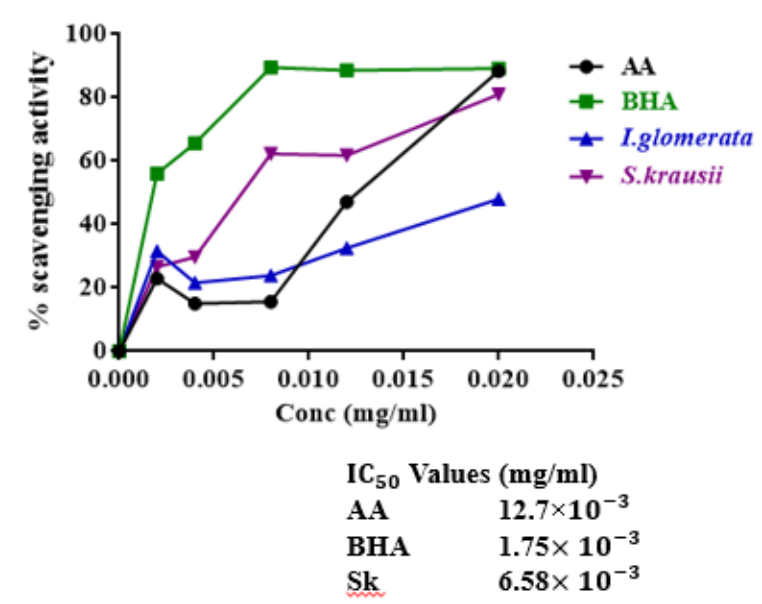

Figure No. 2

Scavenging effects of Inula glomerata and Salacia krausii on (a) DPPH (b) ABTS. Sign notations: AA ascorbic acid, BHA Butylated hydroxyanisole, Sk Salacia krausii 
Nitric oxide (NO') scavenging activity

Figure No. 3 depicted the scavenging activity of the crude extract of the plants on nitric oxide radicals. The result indicated that Inula glomerata and Salacia kraussii showed minimum nitric oxide radical scavenging activities at lower concentrations and had no effect at higher concentrations. Overall, both crude extracts are poor scavengers of nitric oxide radicals.

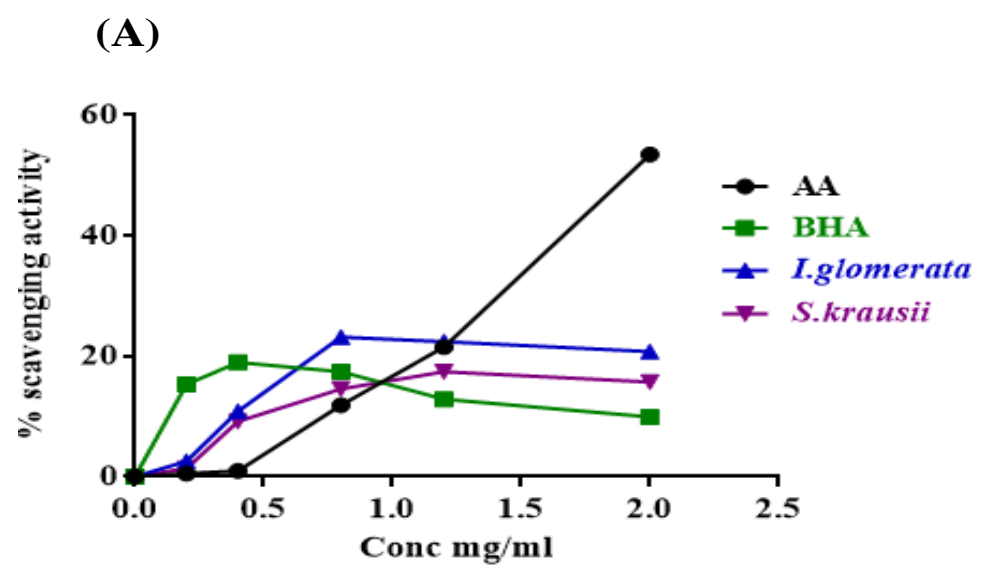

Figure No. 3

Scavenging activity of Inula glomerata and Salacia krausii on nitric oxide radical

\section{The level of glutathione in the serum}

The level of glutathione is depicted in Figure No. $4 \mathrm{a}$. The level of glutathione was significantly diminished in the untreated group when compared with the normal. However, at low concentration $(50 \mathrm{mg} / \mathrm{kg}$ b.w) only I. glomerata markedly increased glutathione level more than the n-butanol induced rats (Figure No. 4a).

\section{Malondialdehyde level in the serum}

The crude extracts of the plants at both concentrations, markedly reduced malondialdehyde level from that observed in the untreated n-butanol group as seen in Figure No. 4b. At low concentration $(50 \mathrm{mg} / \mathrm{kg} \mathrm{b.w})$, the crude extracts, significantly decreased malondialdehyde level compared to the untreated n-butanol group and non-significantly when compared with the normal group. In addition, at high concentrations $(250 \mathrm{mg} / \mathrm{kg} \mathrm{b.w})$, the crude extracts of the plants non-significantly lowered malondialdehyde level compared to the untreated n-butanol-induced rats. Crude extracts at low concentrations exhibited the same effect on the malondialdehyde level as Cialis, the positive control (Figure No. 4b).

Boletín Latinoamericano y del Caribe de Plantas Medicinales y Aromáticas/422 
(A)

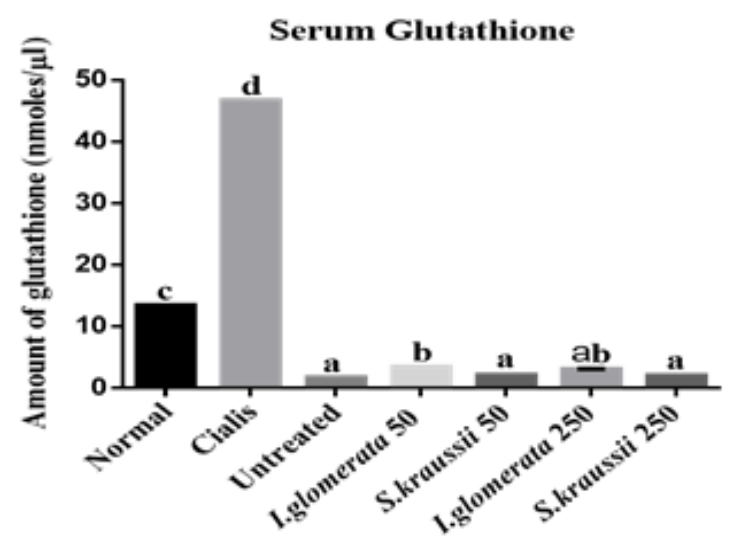

(B)

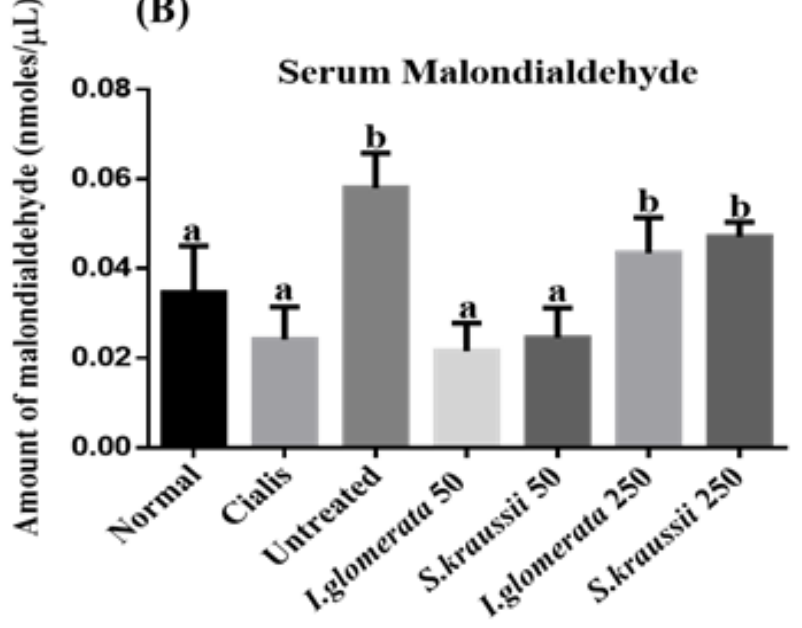

Figure No. 4

Effect of the crude extracts on (a) glutathione (b) malondialdehyde level in the serum. Bars with different alphabets indicate a significant difference $(p<0.05)$. The values are mean $\pm \operatorname{SD}(n=5)$
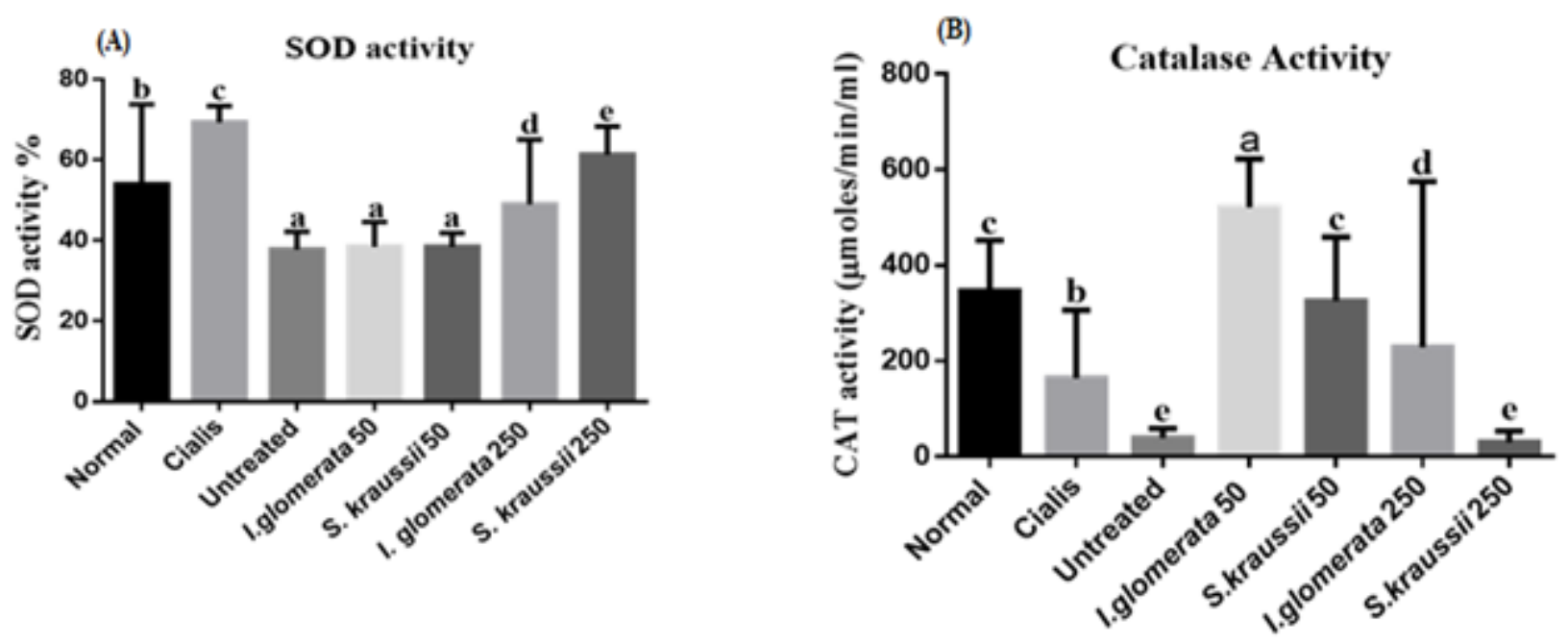

Figure No. 5

Antioxidant status modulation of the crude extracts on (a) SOD (b) CAT activities in the serum. The bars with different alphabets denote a significant difference $(p<0.05)$. Bars with different alphabets indicate a significant difference $(p<0.05)$. The values are mean \pm SD $(n=5)$ 


\section{The activities of Super oxide dismutase (SOD) in the serum}

Superoxide dismutase activities were compromised in the n-butanol induced rats as represented in figure 5a. However, the crude extracts at low concentrations $(50 \mathrm{mg} / \mathrm{kg}$ b.w) had no effect on SOD activities whereas at high concentrations $(250 \mathrm{mg} / \mathrm{kg}$ b.w $)$, significantly augmented SOD activities with $S$. krausii having the greater impact (between both plants) and almost on par compared to the positive control (Cialis).

\section{The activities of Catalase (CAT) in the serum}

Figure No. 5b depicted the effect of the crude plants' extracts on CAT activities. The activities of CAT were significantly reduced in the n-butanol induced rats compared to the normal rats. However, $I$. glomerata at both concentrations (50 and $250 \mathrm{mg} / \mathrm{kg}$ b.w) significantly elevated CAT activities compared to the untreated. Furthermore, I. glomerata at low concentration $(50 \mathrm{mg} / \mathrm{kg}$ b.w $)$ exhibited the greatest positive effect on CAT activities. Contrastingly, $S$. krausii only at low concentration $(50 \mathrm{mg} / \mathrm{kg}$ b.w) markedly increased CAT activity.

\section{DISCUSSION}

Free radicals mediated cellular damages such as lipid peroxidation, alteration of membrane fluidity, DNA disruption and impaired platelet aggregation play prominent role in the development and pathogenesis of several disease conditions including cancer, cardiovascular diseases, diabetes mellitus and erectile dysfunction (Buford, 2016; Majzoub \& Agarwal, 2017; Ojo et al., 2019). Compounds with antioxidant potentials are becoming increasingly prominent in the combat of these diseases.

DPPH and ABTS are artificial free radicals with a similar mechanism of actions as lipophilic radicals that initiate chain reactions through lipid autoxidation (Lawal et al., 2015). Hence, are used to evaluate the scavenging efficacies of crude extracts (Majzoub \& Agarwal, 2017; Ojo et al., 2019). It is apparent from this study that the crude extracts of the plants under study exhibited poor free radicals scavenging potentials (Figures No. 2a and Figure No. 3). Halliwell (2011), Leiser \& Miller (2010), as well as Kaspar et al. (2009) have argued that poor antioxidants (pro-oxidants) could augment endogenous antioxidants, providing better antioxidant defense in humans.

Superoxide dismutase (SOD) and catalase (CAT) are the first lines of defense of cells and tissues against endogenous and exogenous free radicals (Raja \& Ravindranadh, 2017). Therefore, boosting endogenous antioxidants can help to prevent free radicals induced pathologies (Azadzoi \& Siroky, 2009; Erukainure et al., 2014; Oboh et al., 2015). It was recorded in this study that the crude extracts augmented SOD and CAT activities (Figure No. 5a and Figure No. 5b). The elevated glutathione (Figure No. 4a) and concomitantly markedly diminished malondialdehyde level (Figure No. 4b) attest to the in vivo antioxidant potential of the plants. Such properties could contribute to the bioactivities of these medicinal plants as used by traditional healers.

Nitric oxide radical reacts with superoxide anions $\left(\mathrm{O}^{--}\right)$and hydroxyl radicals $(\mathrm{OH})$ to generate peroxynitrites. These nitrogen reactive species enhance lipid peroxidation and nitration that elevate malondialdehyde and hydroperoxide production. These cytotoxic products induce cellular structural changes that eventually lead to oxidative stress and cell deaths (Lawal et al., 2015; Oboh et al., 2015). The observed poor nitric oxide scavenging activities of the plants' extracts (Figure No. 3) implies that these crude extracts might not prevent deleterious effects associated with peroxynitrites accumulation. However, because of the biological significance of nitric oxide in penile erection physiology (Andersson, 2011; Fraga-Silva et al., 2013; Oboh et al., 2015), it is apparent that a poor nitric oxide scavenger (as exhibited by the plants under study) can contribute to the management of erectile dysfunction.

Polyphenols which are secondary metabolites commonly found in fruits and vegetables are predominantly the antioxidants in human diets (Oboh \& Rocha, 2007). Therefore, it can be inferred that the phenolics and flavonoids are responsible for the antioxidant properties displayed by the crude extracts. These compounds have polyunsaturated heterocyclic ring structures that are stabilized through resonance effect when they terminate free radicals progressive lipophilic attack through abstract proton (Coman et al., 2012; Erukainure et al., 2014; Ojo et al., 2019).

In conclusion, Inula glomerata and Salacia kraussii boosted endogenous antioxidants in an erectile dysfunctional rat model, therefore, they could serve as a natural antioxidant source with the potential to prevent oxidative stress-related pathologies including erectile dysfunction. Consequently, the plants have the potency to promote health and vitality. The study was a preliminary study to scientifically justify the use of the plants in 
Ayurvedic medicine hence for further studies, comprehensive phytochemical constituents of the plants will be elucidated using HPLC as well as isolation of the bioactive compounds.

\section{ACKNOWLEDGMENTS}

The authors acknowledge National Research Foundation and Research office of University of Zululand for her financial supports.

\section{REFERENCES}

Andersson KE. 2011. Mechanisms of penile erection and basis for pharmacological treatment of erectile dysfunction. Pharmacol Rev 63: 811 - 859. https://doi.org/10.1124/pr.111.004515

Arumugam P, Murugan M, Thangaraj N. 2012. Evaluation of anti-inflammatory and analgesic effects of aqueous extract obtained from root powder of Inula racemose Hook.f. J Med Plant Res 6: 2801 - 2806. https://doi.org/10.5897/jmpr11.1196

Azadzoi KM, Siroky M. 2009. Oxidative stress and molecular reactions in arteriogenic erectile dysfunction. Chonnam Med J 45: 1 - 8. https://doi.org/10.4068/cmj.2009.45.1.1

Badami S, Rai SR, Suresh B. 2005. Antioxidant activity of Aporosa lindleyana root. J Ethnopharmacol 101: 180 184. https://doi.org/10.1016/j.jep.2005.04.029

Bandeira SO, Gaspar F, Pagula FP. 2001. African ethnobotany and healthcare: emphasis on Mozambique. Pharm 39: 70 - 73. https://doi.org/10.1076/phbi.39.7.70.5873

Bhakuni P, Chandra M, Misra MK. 2005. Levels of free radical scavengers and antioxidants in post-reperfused patients of myocardial infarction. Curr Sci 89: 168 - 170.

Brand-Williams W, Cuvelier ME, Berset CL. 1995. Use of a free radical method to evaluate antioxidant activity. LWT-Food Sci Technol 28: 25 - 30. https://doi.org/10.1016/s0023-6438(95)80008-5

Buford TW. 2016. Hypertension and aging. Ageing Res Rev 26: 96 - 111.

Burrows JE, Willis CK. 2005. Plants of the Nyika Plateau Southern African Botanical Diversity Network Report No. 31 SABONET, Pretoria, South Africa.

Coman C, Rugina OD, Socaciu C. 2012. Plants and natural compounds with antidiabetic action. Notulae Botanicae Horti Agrobotanici Cluj-Napoca 40: 314 - 325. https://doi.org/10.15835/nbha4017205

Erukainure OL, Ebuehi OA, Choudhary IM, Adhikari A, Hafizur RM, Perveen S, Muhammad A, Elemo GN. 2014. Iridoid glycoside from the leaves of Clerodendrum volubile beauv. shows potent antioxidant activity against oxidative stress in rat brain and hepatic tissues. J Diet Suppl 11: 19 - 29. https://doi.org/10.3109/19390211.2013.859213

Fraga-Silva RA, Montecucco F, Mach F, Santos RA, Stergiopulos N. 2013. Pathophysiological role of the reninangiotensin system on erectile dysfunction. Eur J Clin Invest 43: 978 - 985.

https://doi.org/10.1111/eci.12117

Garza RG, Lopez MA, Perez-Vertti, RD, Orasma CL, Martinez JM. 2015. Testicular damage in Wistar rats caused by methanolic extracts of plants from the North of Mexico. J Med Plant Res 9: 724 - 730.

https://doi.org/10.5897/jmpr2015.5846

Halliwell B. 2011. Free radicals and antioxidants-quo vadis?. Trends Pharmacol Sci 32: 125 - 130. https://doi.org/10.1016/j.tips.2010.12.002

Harbone JB. 1973. Phenolic compounds. Phytochem Anal 271 - 280.

Kaspar JW, Niture SK, Jaiswal AK. 2009. Nrf2: INrf2 (Keap1) signaling in oxidative stress. Free Radical Biol Med 47: 1304 - 1309. https://doi.org/10.1016/j.freeradbiomed.2009.07.035

Kujala TS, Loponen JM, Klika KD, Pihlaja K. 2000. Phenolics and betacyanins in red beetroot (Beta v ulgaris) root: Distribution and effect of cold storage on the content of total phenolics and three individual compounds. J Agr Food Chem 48: 5338 - 5342. https://doi.org/10.1021/jf000523q

Lavanya V, Ganapathy D, Visalakshi RM. 2019. Antioxidant and free radical scavenging activity of Ocimum Basilicum- An in vitro study. Drug Invention Today 12: 1004 - 1007.

Lawal OA, Ojekale AB, Oladimeji OS, Osinaike TS, Sanni AA, Simelane MB, Mosa RA, Opoku AR. 2015. Antioxidant activity, total phenolic and flavonoid contents of essential oils of three Cyperus species (Cyperaceae). Br J Pharmaceut Res 7: 52 - 62. https://doi.org/10.9734/bjpr/2015/18631

Leiser SF, Miller RA. 2010. Nrf2 signaling, a mechanism for cellular stress resistance in long-lived mice. Mol Cell Biol 30: 871 - 884. https://doi.org/10.1128/mcb.01145-09 
Majzoub A, Agarwal A. 2017. Antioxidant therapy in idiopathic oligoasthenoteratozoospermia. Ind J Urol 33: 207. https://doi.org/10.4103/iju.iju_15_17

Muraoka O, Morikawa T, Miyake S, Akaki J, Ninomiya K, Yoshikawa M. 2010. Quantitative determination of potent $\alpha$-glucosidase inhibitors, salacinol and kotalanol, in Salacia species using liquid chromatographymass spectrometry. J Pharmaceut Biomed Anal 52: 770 - 773.

https://doi.org/10.1016/j.jpba.2010.02.025

Oboh G, Rocha JB. 2007. Distribution and antioxidant activity of polyphenols in ripe and unripe tree pepper (Capsicum pubescens). J Food Biochem 31: 456 - 473. https://doi.org/10.1111/j.1745-4514.2007.00123.x

Oboh G, Ademiluyi AO, Ademosun AO, Olasehinde TA, Oyeleye SI, Boligon AA, Athayde ML. 2015. Phenolic extract from Moringa oleifera leaves inhibits key enzymes linked to erectile dysfunction and oxidative stress in rats' penile tissues. Biochem Res Int Vol 2015, Article 175950, 8 pages

https://doi.org/10.1155/2015/175950

Odebiyi OO, Sofowora EA. 1978. Phytochemical screening of Nigerian medicinal plants II. Lloydia 41: 234 - 246.

Office of Laboratory Animal Welfare. 2015. Public Health Service policy on humane care and use of laboratory animals. NIH https://olaw.nih.gov/policies-laws/phs-policy.htm

Ojo MC, Osunsanmi FO, Zaharare GE, Mosa RA, Cele, ND, Oboh MO, Opoku AR. 2019. In-vitro anti-diabetic and antioxidant efficacy of methanolic extract of encephalartos ferox leaves. Pharmacogn Magazine 11: 455 - 460. https://doi.org/10.5530/pj.2019.11.71

Ordonez AA, Gomez JD, Vattuone MA. 2006. Antioxidant activities of Sechium edule (Jacq.) Swartz extracts. Food Chem 97: 452 - 458. https://doi.org/10.1016/j.foodchem.2005.05.024

Pendyala G, Thomas B, Kumari S. 2008. The challenge of antioxidants to free radicals in periodontitis. J Ind Soc Periodontol 12: 79 - 83. https://doi.org/10.4103/0972-124x.44100

Raimondo D, Staden LV, Foden W, Victor JE, Helme NA, Turner RC, Kamundi DA, Manyama PA. 2009. Red list of South African plants 2009. SANBI.

Raja S, Ravindranadh K. 2017. In vivo activity of Limnophila heterophylla and Michelia Champaca. Int J Pharm Pharmacol 9: 241 - 246. https://doi.org/10.22159/ijpps.2017v9i12.22013

Re R, Pellegrini N, Proteggente A, Pannala A, Yang M, Rice-Evans C. 1999. Antioxidant activity applying an improved ABTS radical cation decolorization assay. Free Radic Biol Med 26: 1231 - 1237. https://doi.org/10.1016/s0891-5849(98)00315-3

Reena SR, Arputha Sundar WAS, Sandhya SM, Dhanya S, Gopal L. 2018. A review on free radicals and antioxidants. Indo Am J Pharmaceut Sci 5: 11541 - 11548.

Tan RX, Tang HQ, Hu J, Shuai B. 1998. Lignans and sesquiterpene lactones from Artemisia sieversiana and Inula racemosa. Phytochemistry 49: 157 - 161. https://doi.org/10.1016/s0031-9422(97)00889-3

Tsao R, Deng Z. 2004. Separation procedures for naturally occurring antioxidant phytochemicals. J Chromatogr B 812: 85 - 99. https://doi.org/10.1016/s1570-0232(04)00764-0 